\section{Fastlegers stabilitet}

Nordmenn er gjennomgående fornøyd med fastlegene og den kontinuiteten de representerer. Det er vanlig å anta at kontinuitet er et kvalitetskriterium og at stabile primærleger er et gode. Evaluering av fastlegereformen viste da også at kontinuitet var et hovedkriterium for pasientene da de skulle velge fastlege (1).

Styringsdata for fastlegeordningen viser at gjennomsnittlig listelengde var 1175 da fastlegeordningen ble innført i 2001 (2). Først i 2012 var den så vidt under 1 170. De ti første årene skjedde det altså ingen reell styrking av fastlegeordningen. Økningen i antall hjemler dekket bare befolkningsøkningen. Senere har det skjedd en beskjeden styrking, slik at gjennomsnittlig listelengde ved utgangen av 2014 var 1132.

I den samme perioden har fastlegene fătt utvidet ansvar og flere oppgaver. Den nye akuttmedisinforskriften, med økte kompetansekrav og økt behov for bakvakt, er et av flere eksempler på at nye, ellers rasjonelle, reformer legger økte byrder på fastlegene. Andre eksempler er samhandlingsreformen og den nye fastlegeforskriften. Slike reformer krever økt kapasitet. Ellers trues stabiliteten.

Varighet av fastlegeavtalene er tema for en studie utført ved Nasjonalt senter for distriktsmedisin, og som publiseres i dette nummer av tidsskriftet (3). Abelsen og medarbeidere finner at det er store forskjeller i stabiliteten blant fastlegene. Forskjellene er relatert til kommunestørrelse, listelengde, fastlegens kjønn og alder. Varigheten av fastlegeavtalene var tre ganger så lang i de største kommunene som i de minste. Unge fastleger avsluttet sin fastlegepraksis raskere enn eldre fastleger. De fleste av disse oppdaget trolig at allmennmedisin ikke var riktig karrierevei for dem, og valgte andre karriereveier etterpå. Blant de resterende, som gikk over i en ny fastlegestilling, flyttet de fleste til en større kommune.

Kvinneandelen blant norske leger har vært sterkt økende. Dette avspeiles også i andelen kvinnelige fastleger, som nå er ca. $40 \%$ (2). Det har vært hevdet at kvinner har særlige utfordringer med å være selvstendig næringsdrivende fastlege, og at de oftere velger å hoppe av karusellen (4). Det er derfor noe overraskende når Abelsen og medarbeidere fant at kvinnelige fastleger var mer stabile enn sine mannlige kolleger.

Høy grad av stabilitet er en styrke ved fastlegeordningen. Men det kan også være et problem. Stabiliteten blant eldre fastleger kan blokkere for nyrekruttering og utvidelse av antall hjemler. Det er for tungt å etablere seg med en ny liste (0-liste). Pasientene verdsetter sin fastlege og kontinuiteten så høyt at de tolererer noe dårligere tilgjengelighet. Derfor bytter de ikke til nye leger med mye ledig kapasitet.

I forbindelse med samhandlingsreformen signaliserte daværende helseminister behov for 2200 nye fastleger og mente at maksimal listelengde burde reduseres fra 2500 til ca. 1000 . De som ble kalt «fastlegekongene» skulle miste pasienter (5). Dette bygger imidlertid på misforståelser og mangelfull kunnskap. Det er ikke nødvendigvis de lange listene som er for lange. Listelengde må sees i forhold til fastlegens kapasitet, f.eks. antall dager i kurativ praksis. Fastleger med lange lister har ofte bedre tilgjengelighet enn fastleger med kortere lister (6). Pasientene deres bruker legevakten i mindre grad (7). Abelsen og medarbeidere viser da også at fastleger med lange lister utmerket seg med høy grad av stabilitet. Vi må anta at dette er leger som trives i jobben, og som driver effek- tivt. Økonomi spiller nok også en viktig rolle. Lange lister gir som regel høy inntekt, men kan også kreve betydelige investeringer i utstyr og personell. Det er ikke like lett å forlate dette som det er å si opp en fastlønnsstilling.

Det er et politisk ønske at fastlegene skal ha bedre tilgjengelighet og ta på seg flere oppgaver. Men skal fastlegeordningen styrkes med flere hjemler, må den gjennomsnittlige listelengden reduseres. Det er enkel matematikk. Behovet for listereduksjon kan være større for en deltids fastlege med 800 listepersoner enn for en fulltids fastlege med 2 000. Eksisterende fastleger må aktivt redusere sine lister. Det betyr at en del pasienter vil oppleve uønsket brudd i kontinuiteten og vil måtte bytte til nye fastleger. Samtidig må det gjøres noe med finansieringsordningen. Det nåværende basistilskuddet per listeperson er et sterkt incitament til å ta på seg for lange lister. Vi trenger en finansieringsordning som gjør det kostnadsnøytralt for legene å redusere listen og heller yte mer for hver enkelt pasient (8).

Det bør vurderes å avvikle basistilskuddet, i alle fall i sin nåværende form. Den gamle ordningen med driftstilskudd hadde imidlertid også sine svakheter. Kommunene vegret seg for å opprette nye hjemler fordi det medførte økte kostnader. En modell kan være at hele finansieringen av fastlegeordningen baseres på egenandeler og trygderefusjon. Da vil det også være lettere å styre praksis i ønsket retning ved hjelp av økonomiske incentiver. Videre bør det være adgang til å forsøke seg som fastlege uten å ta på seg store økonomiske forpliktelser. Det kan selvsagt skje i form av et vikariat, men det er også mange unge leger som foretrekker en fastlønnsstilling i denne fasen av karrieren. Det viktigste tiltaket for å ta vare på de unge fastlegene vil likevel være tilrettelagte utdanningsstillinger, med god veiledning.

\section{Hogne Sandvik}

hogne.sandvik@isf.uib.no

Hogne Sandvik (f. 1954) er dr.med. og spesialist i allmennmedisin, fastlege ved Morvik legekontor og forsker ved Nasjonalt kompetansesenter for legevaktmedisin, Uni Research Helse.

Forfatter har fylt ut ICMJE-skjemaet og oppgir ingen interessekonflikter.

\section{Litteratur}

1. Sandvik H. Evaluering av fastlegereformen 2001-2005. Sammenfatning og analyse av evalueringens delprosjekter. Oslo: Norges forskningsråd, 2006.

2. Fastlegestatistikk. Utviklingstrekk og endringer i fastlegeordningen. https://helsedirektoratet.no/statistikk-og-analyse/fastlegestatistikk (9.11. 2015).

3. Abelsen B, Gaski M, Brandstorp H. Varighet av fastlegeavtaler. Tidsskr Nor Legeforen 2015; 135: 2045-9

4. Wennevold K. Arbeidsvilkår i allmennmedisin - modent for revisjon? http://legeforeningen.no/lokal/troms/Skalpellen/ Arbeidsvilkar-i-allmennmedisin--modent-for-revisjon/ (9.11. 2015).

5. Nielsen A, Stølan J. Fastlegekongene skal miste pasienter. VG 16.2. 2009.

6. Godager G, Iversen T. Brukernes erfaringer med fastlegeordningen 2001-2012. Trender i bruk, tilgjengelighet og fornøydhet. HERO Skriftserie 2014: 2. Oslo: Helseøkonomisk forskningsnettverk, Universitetet i Oslo.

7. Sandvik H, Hunskår S, Diaz E. Fastlegepasienters bruk av legevakt. Tidsskr Nor Legeforen 2012; 132: 2272-6.

8. Utviklingsplan for fastlegeordningen 2015-2020. http://legeforeningen.no/yf/ Allmennlegeforeningen/Nyheter/2014/Utvilingsplan-for-fastlegeordningen/ (9.11. 2015). 